Journal of Biotechnology and Strategic Health Research

Derleme / Review

http://dergipark.org.tr/tr/pub/bshr

\title{
Diş Hekimliği ve Dental Klinikler Yönünden COVID-19 Enfeksiyonu
}

\author{
COVID-19 Infection in Terms of Dentistry and Dental Clinics
}

\section{Doğukan Yılmaz}

Sakarya Üniversitesi, Diş Hekimliği Fakültesi, Periodontoloji AD.

ORCID ID: Doğukan Yılmaz 0000-0003-2576-0885

*Sorumlu Yazar / Corresponding Author: Dr.Öğr.Üyesi Doğukan Yılmaz, e-posta / e-mail: dogukanyilmaz@sakarya.edu.tr

Geliş Tarihi / Received : 31-03-2020 Kabul Tarihi / Accepted: 02-04-2020 Yayın Tarihi / Online Published: 10-04-2020

Atıf Gösterimi/How to Cite: Yılmaz D., Diş Hekimliği ve Dental Klinikler Yönünden COVID-19 Enfeksiyonu, J Biotechnol and Strategic Health Res. 2020;1(Özel Sayı):22-28

$\ddot{\mathrm{O} z}$

2019 yılı sonunda COVID-19 olarak tanımlanan, atipik ve hızlı yayılabilen bir pnömoni türü tanımlanmıştır. Bu hastalık çok kısa bir süre sonra Dünya Sağlık Örgütü tarafından pandemi olarak ilan edilmiştir. Dental işlemler esnasında oluşan damlacık ve aerosoller ile kontamine olan hekim, hasta ve çalışanlar dental klinik ortamını hızla enfekte ederek hastalığın yayılmasına sebep olabilirler. Bu salgın ortamında diş hekimleri ve yardımcılarına da salgının yayılmasının önüne geçilmesi aşamasında önemli görevler düşmektedir. Hastalığın bulaş ve yayılması açısından oldukça riskli alanlardan biri olan diş kliniklerinde, acil sağlık hizmetlerini aksatmadan, alınacak en yüksek tedbir ve dikkatle bu sürecin yönetimi yapılmadır. Bu derlemede diş hekimlerine klinikte alabilecekleri önlemlerle ilgili ilgili bilgiler sunulmuştur.

Anahtar COVID-19, diş hekimliği, enfeksiyon kontrolü.

Kelimeler

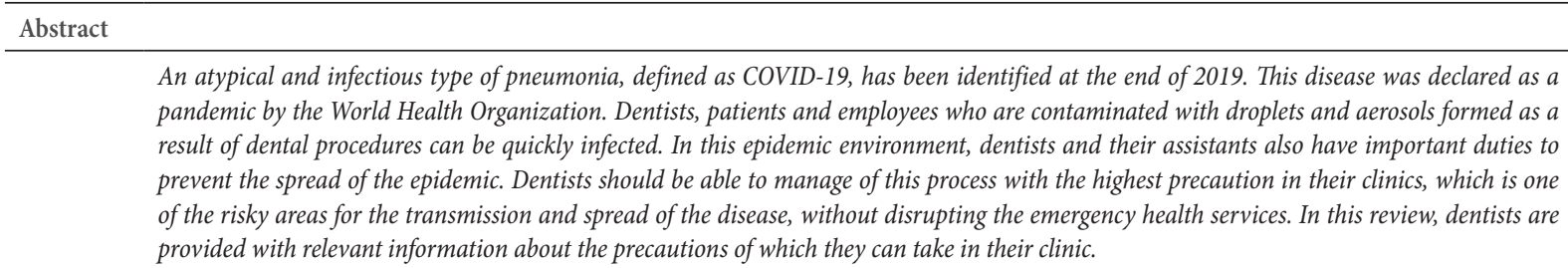

Keywords COVID-19, dentistry, infection control. 


\section{GIIRIŞ}

2019 Aralık ayında Çin'in Hubai eyaletinin Wuhan şehrinde sağlık otoriteleri, atipik ve hızlı yayılabilen bir pnömoni türü görülmüştür. 8 Ocak 2020 tarihinde, Çin Hastalık Kontrol ve Önleme Merkezi tarafından hastalığın etken patojeni COVID-19 olarak belirlenmiştir. ${ }^{1} \mathrm{Bu}$ patojen başlangıçta 2019-nCoV olarak isimlendirilmiş ancak resmi olarak ciddi akut respiratuar sendrom koronavirus-2 (SARS-CoV-2) olarak tanımlanmıştır. ${ }^{2}$ Hastalığın tanımlanmasıyla beraber, bulaş hızla artmış ve hastalık bölgesel sınırından çıkarak global bir yayılım göstermiştir. 30 Ocak 2020 tarihinde, Dünya Sağlık Örgütü (DSÖ) bu özgün pnömoni tablosunu, uluslararası halk sağlı̆̆ını tehdit eden bir salgın olarak duyurmuştur. ${ }^{3}$ Mart ayı itibarı ile 185 ülkede enfekte vakaların görülmesi ile beraber, 11 Mart 2020 tarihi itibari ile DSÖ tarafından pandemi olarak ilan edilmiştir. ${ }^{4}$

Koronavirüsler, coronaviridae ailesine aittir bu aileye ait virüslerin çoğu memeli ve omurgalılarda, solunum, gastrointestinal ve merkezi sinir sisteminde enfeksiyon geliştirebilmektedir. ${ }^{5} \beta$-CoV ailesine dahil olan, SARS-CoV-2 virüsü fetal ve ciddi respiratuar hastalıklara sebep olan SARS-CoV ve Orta doğu respiratuar sendrom koronavirüs (MERS-CoV) ile aynı grupta bulunmaktadır ancak yapılan güncel araştırmalara göre, bu 2 virüsle genetik benzerliği \%80'in altındadır ve bulaş hızı bu iki virüse göre belirgin derecede fazladır. ${ }^{6,7}$ SARS-CoV-2 virüsünün hayvansal kaynaklı olduğu, primer orjininin Rhinolophus affinis türü yarasalarda izole edildiği tespit edilmiştir. ${ }^{8}$ Ancak kaynak kabul edilen virüsle arasındaki farklılıklardan dolayı, virüsün bulaşında ara basamakların olabileceğini akla getirmiştir, Güney Çin Tarım Üniversitesinden bir grubun yaptığı araştırmada pangolinlerden izole edilen $\beta$-CoV virüsler ile SARS-CoV-2 arasında genom sekans benzerliği \%99 olarak tespit edilmiş ve ara konağın bu hayvanlar olabileceği düşünülmüştür. ${ }^{9}$

SARS-CoV-2 enfekte vakaların çoğu semptomları hafif, orta şiddette geçirmektedir. Vakaların çoğunda kuru ök- sürük, ateş semptomları gözükürken, daha az vakada nefes darlığı, yorgunluk şikayetleri bildirilmiştir. Bunu dışında kas ağrısı, baş ve boğaz ağrısı, diyare, bulantı gibi atipik semptomlar mevcuttur. Tüm yaş gruplarını etkilemekle beraber, altta yatan sistemik hastalığı bulunan popülasyonlarda, 65 yaş üstü bireylerde hem klinik tablo ağırlaşmakta hem de mortalite oranları artmaktadır. ${ }^{10}$ Hastalığın teşhisinde, belirlenen risk faktörlerine maruziyet ile ilgili detaylı anamnez, vital bulguların ölçümü, belirgin semptomların tespit edilmesi, çift taraflı gögüs tomografisinde buzlu cam görüntüsü ve RT-PCR metoduyla virüsün tespit edilmesi yöntemlerine başvurulmaktadır. ${ }^{11}$ Virüsün inkübasyon süresi ortalama 5-6 gün olarak tanımlanmakla beraber 14 güne kadar uzadığı belirtilmiştir. ${ }^{12}$

SARS-CoV-2 virüsünün de aynı SARS koronavirüsü gibi vücudu giriş yolunda anjiyotensin dönüştürücü enzim II (ACE2) reseptörlerini kullandığ1 gösterilmiştir. ${ }^{13} \mathrm{Bu}$ yüzden ACE2 salınımı gösteren hücreler hedef hücre konumuna düşmekte ve enfeksiyona duyarlı hale gelmektedir. Vücutta en çok ACE2 salınımı yapan hücrelere; akciğerdeki tip II alveol hücreleri, özefagustaki çok katlı epitel hücreleri, ileum ve kolondaki enterositler, böbrek proksimal tübü hücreleri örnek verilebilir. ${ }^{14}$ Virüs yaygın olarak direk temas (öksürük, hapşırık, damlacık inhalasyonu) ve kontakt transmisyon yolu (kontamine oral, nazal, göz mukoza teması) ile ve nispeten daha az oranda fekal-oral yollarla bulaşmaktadır. ${ }^{15}$ Semptomatik hastalar bulaş yollarında ana kaynak olarak görülmekle beraber, asemptomik virüs taşıyıcı bireylerin de virüs bulaşında etkili olduğu gösterilmiştir. Bu nedenle ilgili kişilerin tespiti ve izolasyonları sıkıntı yaratmaktadır.

Oral kavite, farklı tipte epitel hücreleri yönünden zengin bir alandır. Oral kavitede dil, bukkal mukoza, gingiva ve özellikle tükürük bezi kanallarında ACE2 ekspresyonu yapabilen hücreler mevcuttur 16 ve yapılan bir çalışmada salyada ilgili virüsün izole edilebildiği gösterilmiştir. ${ }^{17}$ Tüm bu veriler bulaş yollarına ek olarak, oral kaviteyi de hastalığın bulaş ve yayılması açısından riskli bölgelerden 
biri haline getirmektedir.

\section{Dental Kliniklerde COVID-19 için Potansiyel Bulaş Yolları}

Dental uygulamalar; hastayla hekimin yakın temas halinde bulunduğu, hekimin ve çalışanların çoğu zaman kan, salya gibi vücut sıvılarına maruz kaldığı, oral, mukozal ve nazal mukozaya temas edilen ve bazı durumlarda yüksek devirli, sivri, kesici, delici aletlerin kullanıldığı işlemlerden oluşur. Yüksek devirli bu aletlerin, canlı dokulara zarar vermesini önlemek için işlemler su soğutması ile yapılmaktadır. Bu durumda fazla miktarda aerosol oluşmaktadır. Oluşan bu aerosoller, hastanın salyası hatta bazı zamanda kanı ile kontamine olmaktadır. ${ }^{18} \mathrm{Su}$ soğutmalı bu işlemler bazı hastalarda tükürme ve öksürme gibi davranışları da tetikleyebilmektedir. Aerosoller canlı ve cansız yüzeylere de tutunabilme özelliklerinin dışında havada birkaç saate kadar asılı kalabilmektedirler ve bu esnada hasta ve hekimler tarafından inhale edilebilmektedirler. ${ }^{19}$ SARS-CoV-2 virüsün bulaş mekanizması göz önüne alındığında diş hekimliği pratiği ve dental işlemler sonucu oluşan bu aerosoller önemli bir risk oluşturmaktadır. ${ }^{2,3}$ Bunun haricinde insan korona virüslerinin, metal, cam, plastik gibi yüzeylerde oda sıcaklığında ve uygun nem koşullarında, birkaç saatten dokuz güne kadar canlı kalabildikleri bilinmektedir. ${ }^{20}$ Dental işlemler sonucu oluşan damlacık ve aerosoller ile kontamine olan hekim, hasta ve çalışanlar dental klinik ortamını hızla enfekte ederek hastalığın yayılmasına sebep olabilirler. Diş hekimliği tedavileri esnasinda virüs ve bakteri bulaşımı eskiden beri var olan büyük bir problemdir ve COVID-19 bulaşı bu problemi daha büyük bir tehlike haline getirmektedir. ${ }^{21,22}$ Enfeksiyonun yayılması ve bulaş hızının düşürülmesi açısından, oldukça riskli olan dental klinik ortam ve çalışanlarının sıkı enfeksiyon kontrol yöntemlerine bağlı kalarak önlemlerini en üst seviyeye çıkarması önerilmektedir.

\section{COVID-19 Enfeksiyonundan Korunmak için} Diş Hekimliği Uygulamaları ve Dental Kliniklerde Alınabilecek Önlemler

Acil Diş Tedavisi Tanımı: COVID-19 salgın önlemleri kapsamında T.C. Sağlık Bakanlığı Sağlık Hizmetleri Genel Müdürlüğünün elektif işlemlerin ertelenmesi ve diğer alınacak tedbirler konulu 17.03.2020 tarihli ve 14500235403.99/00114959156 sayılı yazısının 3. maddesine istinaden, acil olmayan diş hekimliği uygulamalarının mümkün olduğunca ertelenmesi önerilmiştir.

23.03.2020 tarihli Bilim Kurulu’nda alınan kararlara göre; 1- Diş hekimliğinde acil uygulamalar;

1.1. Pulpal inflamasyondan kaynaklanan şiddetli ağrı,

1.2. Perikoronitis veya üçüncü molar diş kaynaklı şiddetli ağr1,

1.3. Postoperatif olarak gelişen osteitis veya alveolit,

1.4. Lokalize ağrı ve şişmeye neden olan apse veya bakteriyel enfeksiyon,

1.5. Ağrı veya yumuşak doku travmasına neden olan diş fraktürü,

1.6. Travmaya bağlı diş avülsiyon/lüksasyonu,

1.7. Çene ve yüz bölgesi fraktürleri,

1.8. Oral mukozanın akut ve ağrılı lezyonları/ülserasyonlar1,

1.9. Hayatı tehdit edici ya da kontrolsüz kanamalar,

1.10. Hastanın havayolu açıklığını tehdit eden intraoral/ ekstraoral enfeksiyonlar,

1.11. Radyoterapi ve kemoterapi alması planlanan ya da almakta olan ve organ nakli planlanan hastaların tedavileri, 1.12.Medikal sorunları için dental konsültasyon istenilen hastalar,

1.13. Dikiş alınması,

1.14. Geçici restorasyon kaybı/kırıklarının ve hareketli protez kullanımına engel olan vurukların aerosol oluşturmayacak şekilde tedavisi,

1.15. Ortodontik tedavi gören hastaların braket ve tellerinin yerinden çıkması veya kırılması şeklinde tanımlanmiştır. 
Ön Değerlendirme: İlk olarak diş hekimleri ve dental klinik çalışanlarının SARS-CoV-2 virüsü konusunda bilgilendirilmesi, özellikle semptom ve bulaş yolları açısından eğitilmeleri gereklidir. Genel olarak COVID-19 semptomları gösteren kişilerin ev veya hastane ortamında izole edilmeleri gereklidir. Ancak bir şekilde bu semptomları gösterdiğinden bilgisi olmadan dental tedaviler için başvuran bireylerin tanımlanması, tanımlanması halinde en yakın sağlık merkezinin bilgilendirilmesi ve bireyin izole edilmesi gerekmektedir. Bu yüzden merkezlere başvuran bireylerin değerlendirilmesi açısından hastaların klinik ortama girişinden önce bir triaj alanı oluşturulması önerilmektedir. ${ }^{2,3} \mathrm{Bu}$ triajda bireylerin ateş ölçümleri temassız alın termometreleri ile yapılmalı ve hastalardan detaylı anamnezleri alınmalıdır. Bu anamnez içerisinde, ${ }^{10,23}$

-Son 14 gün içerisinde, ateşiniz çıktı mı?

-Son 14 gün içerisinde solunum güçlüğü ve/veya kuru öksürük şikayetiniz oldu mu?

-Son 14 gün içerisinde yurtdışı seyahatiniz oldu mu?

-Yakın zamanda toplantı, seminer gibi toplu bir etkinliğe katıldınız mi?

-Son 14 gün içerisinde yakın çevrenizde yurtdışı seyahati yapan biri oldu mu?

-Son 14 gün içerisinde çevrenizde COVID-19 semptomları gösteren biri oldu mu? Sorularının bulunması gereklidir. -Eğer birey bu sorulardan birine "evet" cevabı vermiş ancak ateşi $37,3^{\circ} \mathrm{C}$ 'nin altında ise diş hekiminin tedaviyi en az 14 gün sonrasına ertelemesi ve bireyin ev karantinasına alınarak semptomlarında artış gözlenirse hastaneye başvurması önerilmelidir.

-Birey bu sorulardan en az birine "evet" cevabı vermiş ve ateşi $37,3^{\circ} \mathrm{C}$ 'nin üstünde ise, acil olarak sağlık merkezine haber verilmeli ve hasta izole edilmelidir.

-Birey soruların hepsine "hayır" cevabı vermiş ve ateşi $37,3^{\circ} \mathrm{C}$ 'nin altında ise birazdan belirtilecek önlemler dahilinde tanımlanan acil dental tedaviler yapılabilir.

-Birey soruların hepsine "hayır" cevabı vermiş ancak ateşi $37,3^{\circ} \mathrm{C}$ ve üstü olarak ölçüldü ise, hastaneye veya ilgili sağlık merkezlerine yönlendirilmelidir.

Uygun olan hastaların acil olan diş tedavileri en az iki var- diya olacak şekilde sabit ekipler tarafindan izole odalarda gerçekleştirilmesi ve bu ekibin günlük ateş takiplerinin yapılması önerilmiştir. ${ }^{2,3,10,21}$

Hekim ve Personel için Koruyucu Önlemler: Şu ana kadar, diş hekimliği pratiğinde COVID-19 enfeksiyonundan korunma için özel bir rehberlik hazırlanmamıştır. Hastalığın bulaş riski oldukça yüksek olduğundan dolayı diş hekimleri ve yardımcı personel üç aşamalı koruma yöntemlerine başvurabilirler. Bunlardan 1.seviye koruma; ayaktan hasta departmanları ve triaj bölgeleri için önerilmiştir. Burada koruyucu ekipman olarak; tek kullanımlık cerrahi maske, tek kullanımlık cerrahi bone, iş üniforması, tek kullanımlık lateks veya nitril eldiven ile tek kullanımlık izolasyon giysisi önerilmektedir. ${ }^{24} 2$. Seviye korunma diş hekimliği klinikleri için, şüpheli hastaların işlem ve görüntülemeleri yapılırken ve kullanılmış ekipmanların temizliği aşamalarında tercih edilebilir. Bu seviye korunmada; tek kullanımlık cerrahi bone, koruyucu tıbbi maske (N95), iş kıyafeti, tek kullanımlık koruyucu üniforma, tek kullanımlık lateks veya nitril eldiven, koruyucu gözlük ve/veya yüz siperi önerilmektedir. ${ }^{24} 3$. Seviye korumalar kesin tanı alınmış COVID-19 hastalarında işlem yaparken önerilmektedir. 2. Seviyedeki ekipmanlara ek olarak, tüm yüz solunum koruyucu aletler ya da motorlu hava temizleyici respiratörleri içerir. Ekipmanların giyilme ve çıkarılma sıraları figür 1 ve -2'de özetlenmiştir.

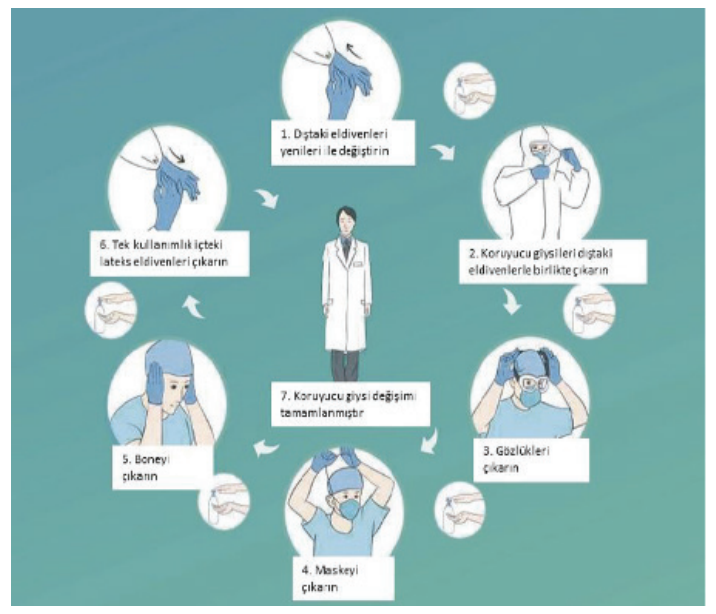

Figür 1: Ekipmanların giyilme sırası. ${ }^{24}$ 


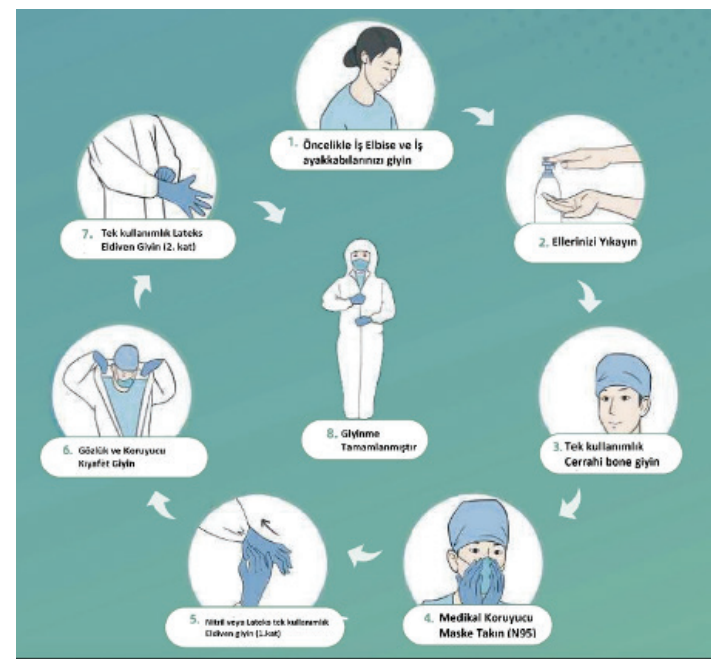

Figür 2: Ekipmanların çıkarılma sırası. ${ }^{24}$

Klinik Uygulama Önerileri: Riski en aza indirmek adına klinik işlemlerde bazı tedbir ve tercihler yapılabilir. Hastadan işlem öncesi bir görüntüleme alınacaksa, salya kontaminasyonunun ve hastanın öğürmesi, öksürmesini tetiklememek adına intraoral radyograflardan kaçınılmalıdır. Ekstraoral yöntemlerle alınacak panaromik veya bilgisayarlı tomografi tercih edilmelelidir. ${ }^{2}$ Hastalığın fekal-oral bulaşı da gösterildikten sonra el yıkamanın önemi bir kez daha gündeme gelmiştir. Zaten dental işlemlerde el yıkama her zaman en yüksek önem gösterilmesi gereken basamaklardan biridir. Hekim, muayeneden önce, işlemden sonra, hastaya dokunduktan sonra, çevre ve ekipmanlara dokunduktan sonra, oral mukoza, vücut sıvısı içeren herhangi bir alana temas ettikten sonra ellerini en az 20 saniye boyunca uygun şekilde yıkamalıdır. Hekim ve yardımcı personelin ellerini yüz bölgesi ile mümkün olan en az şekilde temas etmesine dikkat edilmelidir., ${ }^{2,3}$

İşlem öncesi ağız gargaralarının, oral mikroorganizma sayısını önemli ölçüde azalttığına inanılmaktadır. Virüsün oksidasyona karşı duyarlı olduğu göz önünde bulundurulursa, diş hekimliğinde sık olarak kullanılan klorheksidin gargaraları SARS-CoV-2 virüsüne karşı etkili olmayabilir. ${ }^{3}$ Bunun yerine, $\% 1$ hidrojen peroksit veya $\% 0,2$ povidone gibi oksidatif ajanlarla işlem öncesi gargara yapılması faydalı olacaktır. İşlem süresini, ortam kontaminasyonunu azaltmak, hastanın konforunu arttırmak ve öksürme, ögürme reflekslerini azaltma bakımından işlemler dört elli diş hekimliği yoluyla yapılmalıdır. ${ }^{25}$ İşlemler sırasında, mümkün olduğu kadar hızlı döner ve ultrasonik alet kullanımdan kaçınılmalıdır. İşlemlerde hem kontaminasyonun azaltılması hem de aspirasyonun kolaylığı açısından rubber-dam kullanılması önerilir. İşlemler yüksek emiş gücüne sahip, aspiratörler eşliğinde yapılmalıdır. ${ }^{26}$ Çürük uzaklaştırılmasında kemokimyasal ajanlardan faydalanılabilir. Cerrahi işlemler sonrasında eğer uygunsa rezorbe olabilen süturların kullanımı uygun olacaktır. Hasta randevu aralıklarının uzatılması, işlem sonrası klinik ortamın yaklaşık 15 dakika havalandırılması, yüksek devirli alet kullanılacak hastaların günün son randevusu olarak planlanması alınacak önlemler arasında sayılabilir. ${ }^{2,3}$

Klinik Dezenfeksiyonu ve Tıbbi Atık Yönetimi: Diş hekimliği kliniklerinde dezenfeksiyon ve atık yönetimi işlemleri de en az elektif işlemler kadar kritik öneme sahiptir. Klinik ve ortak alanlarda etkin ve sıkı dezenfeksiyon önlemleri alınmalıdır. Gözle görülür kontaminasyon, dezenfeksiyondan önce tamamen uzaklaştırılmalıdır. Kan ve vücut sıvısı bulaşlarının temizleme prosedürlerine uyulmalıdır. Zemin ve duvarlarda $1000 \mathrm{mg} / \mathrm{L}$ klor içeren dezenfektan ajan kullanılmalıdır. İşlemin en az 30 dakika boyunca yapılması önerilir. Kontaminasyon olduğunda tekrarlanmak koşulu ile günde üç kez dezenfeksiyon işlemleri yapılmalıdır. ${ }^{24} \mathrm{Ci}$ sim yüzeyleri için belirgin kontaminasyon uzaklaştırıldıktan sonra, yüzeyler $1000 \mathrm{mg} / \mathrm{L}$ klor içeren dezenfektan ile silinmeli ve 30 dakika beklendikten sonra temiz su ile durulanmalıdır. Önce temiz alanlar, sonra kontamine alanlar silinmelidir. Kullanılmış silecekler yenisiyle değiştirilmeli ve bu prosedür, kontaminasyon olduğunda tekrarlanmak koşulu ile günde üç kere yapılmalıdır. ${ }^{24}$ Mümkünse, klinik ortam ve ortak alanlar temiz hava ile havalandırılmalı, mümkün değilse plazma hava sterilizatörleri tercih edilmelidir. Ortak alanlarda mümkün olduğu kadar az insanın olması sağlanmalı, burada bulunan insanlara medikal maskeler dağıtılmalıdır. Asansör gibi kapalı ortamlar 
tercih edilmemelidir. Tıbbi atıklar geçici bekleme alanında izole edilmeli, çift katlı tıbbi atık poşetinde muhafaza edilerek poşetler kaz boynu düğüm ile kapatılmalıdır. Tibbi atık prosedürlerine bağlı kalınmaldır.

$\mathrm{Bu}$ salgın ortamında diş hekimleri ve yardımcılarına da salgının yayılmasının önüne geçilmesi aşamasında önemli görevler düşmektedir. Hastalığın bulaş ve yayılması açısından oldukça riskli alanlardan biri olan diş kliniklerinde, acil sağlık hizmetlerini aksatmadan, alınacak en yüksek tedbir ve dikkatle bu sürecin yönetimi yapılmadır.

Açıklamalar: Çalışmayı maddi olarak destekleyen kişi/ kuruluş yoktur ve yazarın herhangi bir çıkar dayalı ilişkisi yoktur. 
J Biotechnol and Strategic Health Res. 2020;1 (Özel Say1):22-28

YILMAZ, COVID-19 ve Diş Hekimliği

\section{Kaynaklar}

1. Lu R, Zhao X, Li J, et al. Genomic characterisation and epidemiology of 2019 novel coronavirus: implications for virus origins and receptor binding. Lancet. 2020;395:565-574.

2. Meng L, Hua F, Bian Z. Coronavirus Disease 2019 (COVID-19): Emerging and Future Challenges for Dental and Oral Medicine. J Dent Res. 2020;22034520914246.

3. Peng X, Xu X, Li Y, et al. Transmission routes of 2019-nCoV and controls in dental practice. Int J Oral Sci. 2020;12:9.

4. World Health Organization. Coronavirus disease 2019 (COVID-19). Situation report 52, 12 March, 2019.

5. Fehr AR, Perlman S. Coronaviruses: an overview of their replication and pathogenesis. Methods Mol Biol. 2015;1282:1-23.

6. Liu J, Zheng X, Tong $Q$, et al. Overlapping and discrete aspects of the pathology and pathogenesis of the emerging human pathogenic coronaviruses SARS-CoV, MERS-CoV, and 2019-nCoV. J Med Virol. 2020;92:491-494.

7. Ji JS. Origins of MERS-CoV, and lessons for 2019-nCoV. Lancet Planet Health. 2020;4:93.

8. Zhou P, Yang XL, Wang XG, et al. A pneumonia outbreak associated with a new coronavirus of probable bat origin. Nature. 2020;579:270-273.

9. Liu P, Chen W, Chen JP. Viral Metagenomics Revealed Sendai Virus and Coronavirus Infection of Malayan Pangolins (Manis javanica). Viruses. 2019;11:979.

10. Chen N, Zhou M, Dong X, et al. Epidemiological and clinical characteristics of $99 \mathrm{ca}$ ses of 2019 novel coronavirus pneumonia in Wuhan, China: a descriptive study. Lancet. 2020;395:507-513.

11. World Health Organization. Clinical management of severe acute respiratory infection when novel coronavirus (2019- $n$ CoV) infection is suspected: interim guidance. 17 February, 2020.

12. Backer JA, Klinkenberg D, Wallinga J. Incubation period of 2019 novel coronavirus (2019$n \mathrm{CoV}$ ) infections among travellers from Wuhan, China, 20-28 January 2020. Euro Surveill. 2020;25:2000062.

13. Wan Y, Shang J, Graham R, et al. Receptor Recognition by the Novel Coronavirus from Wuhan: an Analysis Based on Decade-Long Structural Studies of SARS Coronavirus. J Virol. 2020;94:e00127-20
14. Zou X, Chen K, Zou J, et al. Single-cell RNA-seq data analysis on the receptor ACE2 expression reveals the potential risk of different human organs vulnerable to 2019-nCoV infection. Front Med. 2020;10.1007/s11684-020-0754-0

15. Del Rio C, Malani PN. Novel Coronavirus-Important Information for Clinicians. JAMA. 2020;10.1001/jama.2020.1490.

16. Xu H, Zhong L, Deng J, et al. High expression of ACE2 receptor of 2019- $n \mathrm{CoV}$ on the epithelial cells of oral mucosa. Int J Oral Sci. 2020;12:8.

17. To KK, Tsang OT, Chik-Yan Yip C, et al. Consistent detection of 2019 novel coronavirus in saliva. Clin Infect Dis. 2020;149.

18. 1Cleveland JL, Gray SK, Harte JA, et al. Transmission of blood-borne pathogens in US dental health care settings: 2016 update. J Am Dent Assoc. 2016;147:729-738.

19. Harrel SK, Molinari J. Aerosols and splatter in dentistry: a brief review of the literature and infection control implications. J Am Dent Assoc. 2004;135:429-437.

20. Kampf G, Todt D, Pfaender S, et al. Persistence of coronaviruses on inanimate surfaces and their inactivation with biocidal agents. J Hosp Infect. 2020;104:246-251.

21. McCarthy GM. Risk of transmission of viruses in the dental office. J Can Dent Assoc. 2000;66:554-557.

22. John M. Risk of bacterial transmission in dental practice. J Can Dent Assoc. 2000;66:550552.

23. Wang D, Нu B, Hu C, et al. Clinical Characteristics of 138 Hospitalized Patients With 2019 Novel Coronavirus-Infected Pneumonia in Wuhan, China. JAMA. 2020;e201585.

24. Zhejiang University- Handbook of COVID-19 Prevention and Treatment. 2020.

25. Mamoun J. Basic principles of maximizing dental office productivity. Gen Dent. 2012;60:130-136.

26. Al-Amad SH, Awad MA, Edher FM, et al. The effect of rubber dam on atmospheric bacterial aerosols during restorative dentistry. J Infect Public Health. 2017;10:195-200. 